Jacek $L E Y K O$

\title{
Research on a prototype spark ignition (SI) variable compression ratio engine fitted with a pneumatic energy accumulator
}

\begin{abstract}
The paper describes investigations performed on a prototype variable compression ratio engine fitted with a pneumatic energy accumulator. The engine was built in the Chair of Vehicles and Basics of Machine Design at Lodz University of Technology. Due to the design and principle of operation, the engine may be an alternative to the already existing $V C R$ engines. The pneumatic energy accumulator fitted in the cylinder head with an additional moving piston allows continuous adjustment of the compression ratio. The system is adaptive and adjusts itself to the engine load, reducing the increment of maximum pressure inside the cylinder. The research focuses on the influence of adjustment parameters of the energy accumulator on the movement of the additional piston and engine performance. Engine operation stability and reproducibility of the cycles has also been investigated. An attempt was made to characterize the engine and the energy accumulator in terms of efficiency and range of applicability (profitability of application).
\end{abstract}

Key words: engine, variable compression ratio, pneumatic energy accumulator, prototype, additional piston

\section{Badania prototypowego silnika ZI o zmiennym stopniu sprężania wyposażonego w pneumatyczny akumulator energii}

\begin{abstract}
W artykule opisano badania prototypowego silnika o zmiennym stopniu sprężania wyposażonego w pneumatyczny akumulator energii. Silnik zbudowano w Katedrze Pojazdów i Podstaw Budowy Maszyn Politechniki Łódzkiej. Ze względu na swa konstrukcje $i$ zasade działania jest to pewna alternatywa dla dzisiejszych rozwiniętych już konstrukcji silników $V C R$. Zamontowany w głowicy pneumatyczny akumulator energii z ruchomym dodatkowym tłokiem pozwala na ciagła regulację stopnia sprężania. Regulacja ta jest również adaptacyjna i dostosowuje stopień sprężania do obciążenia silnika, ograniczając wzrost ciśnienia maksymalnego w cylindrze. W badaniach skupiono się nad wpływem parametrów regulacyjnych akumulatora energii na ruch dodatkowego tloka oraz osiagi silnika. Badano także stabilność pracy i powtarzalność cykli. Podjęto próbę scharakteryzowania silnika i pneumatycznego akumulatora energii pod względem sprawności i wyznaczenia przedziatu stosowalności (opłacalności efektów stosowania).
\end{abstract}

Słowa kluczowe: silnik, zmienny stopień sprężania, pneumatyczny akumulator energii, prototyp, dodakowy tłok

\section{Introduction}

One of the ways to boost the efficiency of a combustion engine is to increase the compression ratio. This is particularly the case for spark ignition engines, operating at small or medium loads, when the throttle is half closed and the cylinder filling is low [5]. The compression ratio could then approximate that of diesel engines, yet, under high loads, the properties of gasoline limit the compression ratio to lower values. Such a situation can be remedied by varying of the compression ratio (VCR) where the compression ratio increases along with the reduction of load.

Despite the already existing prototype pre-production VCR engines, the most matured of which are: MCE-5,Saab SVCi Lotus Omnivore $[6,15,13]$, it is still possible to build a VCR engine of a novel design and quite different principle of operation. Such an engine was developed at the Chair of Vehicles and Basics of Machine Design at Lodz University of Technology and the applied solutions are under patent protection [1].

\section{The engine}

The prototype four-stroke engine based on a modified 126A1.076/E unit of Fiat 126 was equipped with entirely new cylinder head in which a pneumatic energy accumula-

\section{Wprowadzenie}

Jednym ze sposobów zwiększenia sprawności silników spalinowych jest podniesienie stopnia sprężania. Dotyczy to szczególnie silników ZI, pracujących pod małym i średnim obciążeniem, gdy przepustnica jest przymknięta, a napełnienie cylindra małe [5]. Stopień sprężania mógłby wówczas dorównywać wartościom stosowanym w silnikach ZS, choć przy dużym obciążeniu właściwości benzyny ograniczają stopień sprężania do wartości niższych. Tak postawione warunki może spełnić silnik o zmiennym stopniu sprężania - VCR (Variable Compression Ratio), w którym stopień sprężania zwiększa się wraz ze spadkiem obciążenia.

Choć powstało już kilka prototypów przedprodukcyjnych silników VCR, wśród których za najbardziej „dojrzałe” można uznać: MCE-5, Saab SVCi Lotus Omnivore [6, 15, 13], to wciąż możliwe jest zbudowanie silnika VCR o nowej konstrukcji i odmiennej koncepcji działania. Silnik taki powstał w Katedrze Pojazdów i Podstaw Budowy Maszyn Politechniki Łódzkiej, a zastosowane w nim rozwiązania chronione są patentem [1].

\section{Badany silnik}

Prototypowy czterosuwowy silnik, który powstał w wyniku modyfikacji silnika 126A1.076/E samochodu 
tor (PEA) with an additional piston was installed [2]. Such a solution allows changing the compression ratio in a continuous way and during the power stroke high pressure inside the cylinder is maintained. Additionally, despite high com-

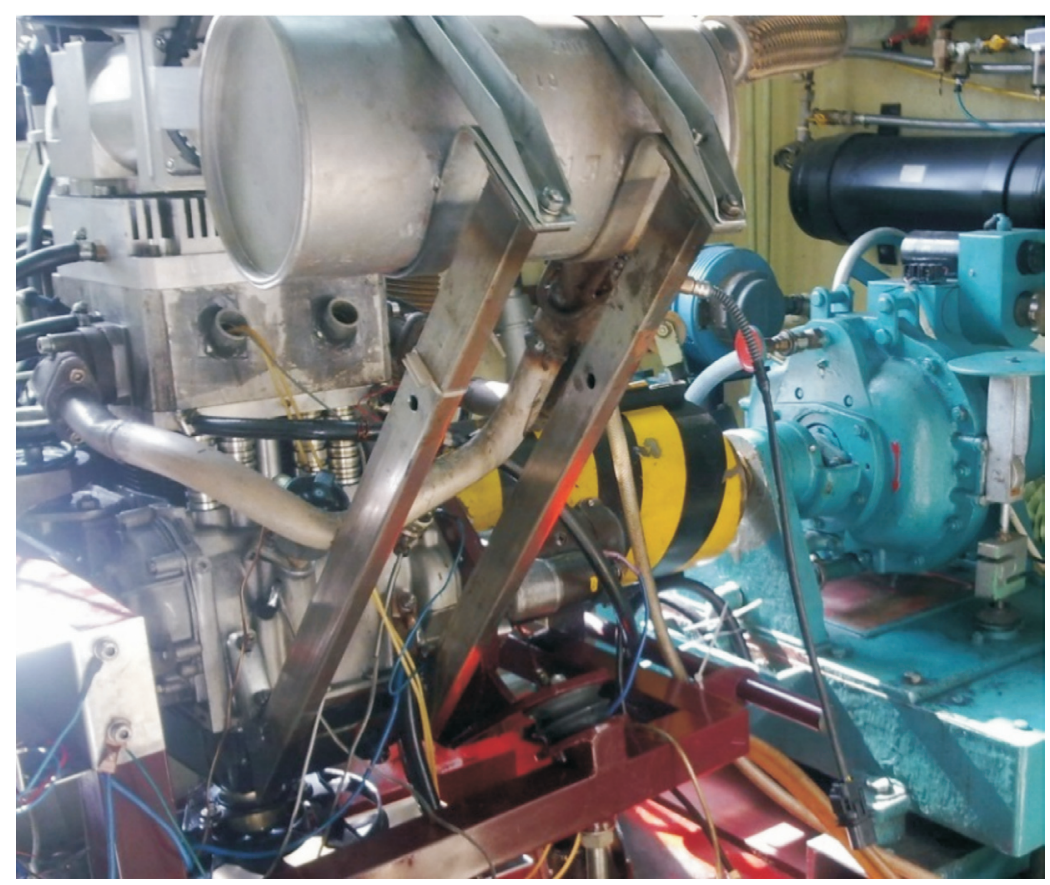

Fig. 1. The prototype engine on the test stand Rys. 1. Prototypowy silnik na stanowisku badawczym

pression ratio, the value of the maximum pressure is close to that of the original engine. The above best describe how an engine with an active and adaptive combustion chamber was developed (Fig. 1).

The diagram explaining the principle of operation of the new cylinder head designed for the prototype engine has been shown in Fig. 2. In the cylinder head, an additional piston was fitted (3), whose flat crown was directed towards the combustion chamber (8) and is its movable wall. The other, glass-shaped side of the piston is located in the compressed air chamber (1) working as a gas spring. The hardness of this spring is adjustable owing to the change of the chamber volume and the initial tension caused by changing the pressure inside the chamber. The glass-shaped piston allows a significant reduction of the pressure in the upper chamber compared to the high pressure in the main engine cylinder, thanks to which the process of pneumatic spring hardness control is much easier.

As long as the resultant force of the cylinder pressure and the pressure in the lower tank (6) is smaller than the force of the air spring above the additional piston, the piston remains in the lowest, zero position and the engine compression ratio is 17 . When the pressure inside the cylinder increases to overcome the initial force of the spring, the piston lifts and the compression ratio is reduced to 8 in the top maximum position. The additional piston serves the purpose of a regulator of the maximum pressure inside the cylinder
Fiat 126 wyposażono w całkowicie zmienioną głowicę, w której zamontowany został pneumatyczny akumulator energii (PAE) z zawieszonym w nim dodatkowym tłokiem [2]. Dzięki takiemu rozwiązaniu stopień sprężania zmienia się w sposób ciągły, a podczas suwu pracy w cylindrze występuje podtrzymanie wysokiego ciśnienia. Dodatkowo, pomimo wysokiego stopnia sprężania, wartość ciśnienia maksymalnego jest zbliżona do wartości panujących w oryginalnym silniku. W ten sposób powstał silnik z aktywną, adaptacyjną komorą spalania (rys. 1).

Schemat ukazujący zasadę działania nowej głowicy, zaprojektowanej dla prototypowego silnika, przedstawiono na rys. 2 . W głowicy umieszczono dodatkowy tłok (3), którego płaskie denko zwrócone jest w stronę komory spalania (8) i stanowi jej ruchomą górną ścianę. Druga strona dodatkowego tłoka, zakończona w kształcie kielicha, znajduje się w zbiorniku ze sprężonym powietrzem (1), spełniającym rolę sprężyny gazowej. Sprężyna ta ma możliwość regulacji sztywności dzięki zmianie objętości zbiornika i napięcia wstępnego przez zmianę ciśnienia panującego w zbiorniku. Kielichowaty kształt tłoka pozwala natomiast na znaczne zmniejszenie ciśnienia w górnym zbiorniku w stosunku do wysokiego ciśnienia w cylindrze głównym

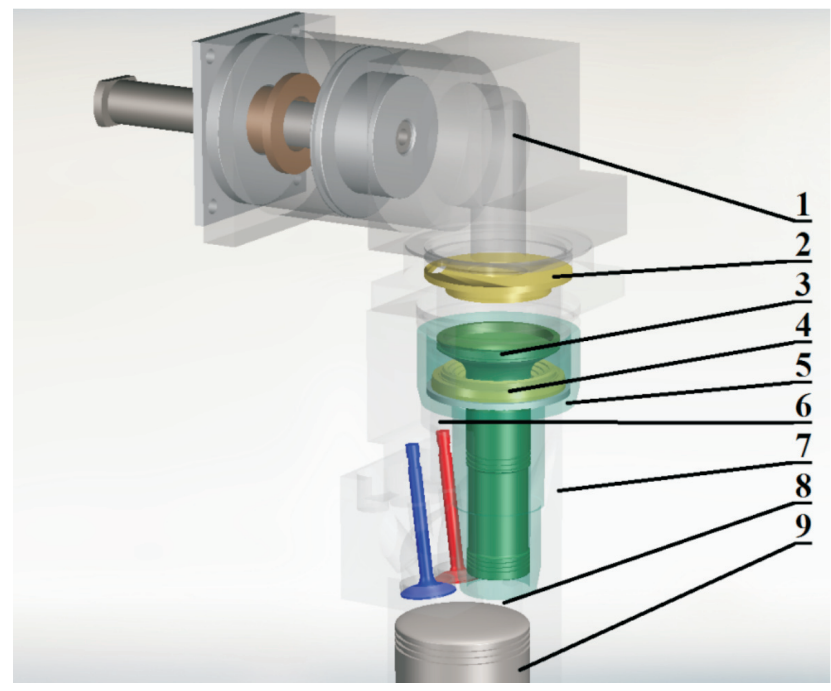

Fig. 2. Schematic diagram of the designed cylinder head: 1 - upper tank above the additional piston with adjustable pressure and volume, 2 - upper bumper, 3 - additional piston, 4 - lower bumper, 5 - additional piston guide sleeve, 6 - lower tank under the part of additional piston with adjustable pressure, 7 - new cylinder head, 8 - combustion chamber, 9 - main piston connected to the engine crankshaft

Rys. 2. Schemat ideowy zaprojektowanej głowicy: 1 - górny zbiornik ponad kielichem tłoka dodatkowego o regulowanym ciśnieniu i objętości,

2 - zderzak górny, 3 - tłok dodatkowy z zakończeniem $w$ ksztatcie

kielicha, 4-zderzak dolny, 5-tuleja prowadzaca dodatkowego tłoka, 6 - dolny zbiornik pod kielichem tłoka dodatkowego o regulowanym ciśnieniu, 7 - nowa głowica silnika, 8-komora spalania, 9-tłok główny silnika połączony z układem korbowym 
and in each cycle its position changes automatically, adapting the compression ratio to a given engine load. Through appropriate pressure and tank (1) volume regulation it is possible to change the range of automatic adjustment of the compression ratio and proper coordination of the piston moving phases with the engine work cycle for a given engine speed and load.

The expected efficiency of the engine fitted with the said cylinder head should be high due to the increased compression ratio and recovery of part of the energy consumed by the PEA during the combustion process. The compression of air in the tank above the additional piston during its upward movement results in energy accumulation that generates certain losses. The energy accumulated in the tank is released to the exhaust gas inside the cylinder during the power stroke when the additional piston moves down returning to its lowest position. When the additional piston returns inside the main cylinder, high pressure is maintained longer than it is in a conventional gasoline engine, though the maximum pressure is limited. When the throttle is half closed and little mixture is fed to the cylinder, an engine with a high compression ratio additionally generates higher maximum pressures inside the cylinder, which also influences its efficiency.

\section{Plan and aim of the research}

The tests of the prototype engine with the additional piston fitted inside the cylinder head were performed on an engine dynamometer at the Chair of Vehicles and Basics of Machine Design of Lodz University of Technology (dynamometer measuring torque and fuel consumption) $[3,7]$. The engine cycle was analyzed based on the analysis of the cylinder pressure and the position of the additional piston inside the cylinder head. For the measurement of the pressure, the authors used AVL $12 \mathrm{QP} 300 \mathrm{cv}$ pressure converter with an amplifier. The piston movement was measured with laser displacement converter (Keyence LK-G152) with a controller. The recording of data was done on a data acquisition card (National Instruments NI USB 6210). The sampling frequency of the measurement signals was limited to $30 \mathrm{kHz}$ due to the limitations of the displacement converter. The course of the measurement and data recording

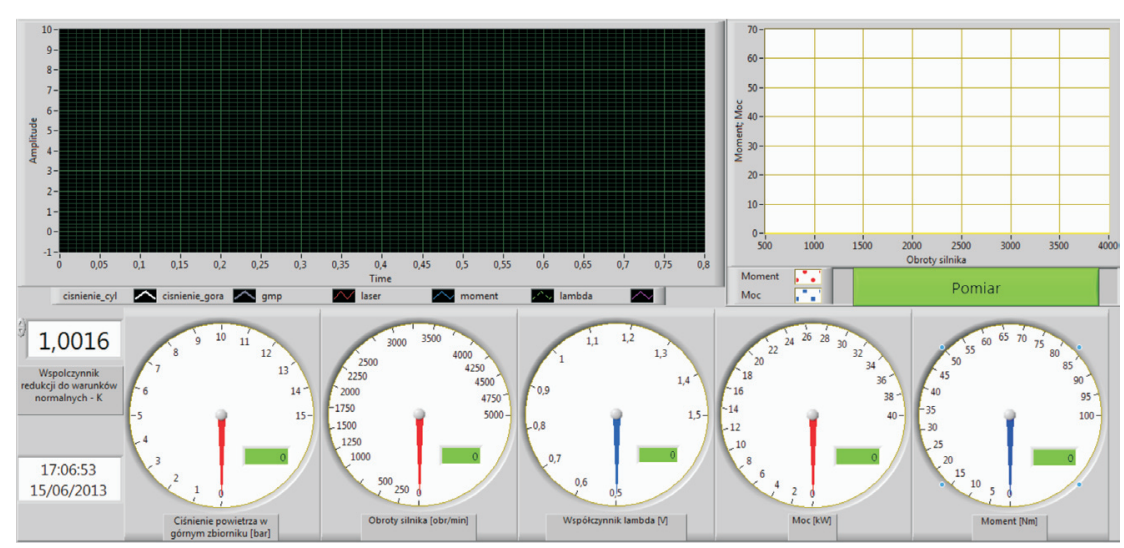

Fig. 3. View of the control panel for the data acquisition program Rys. 3. Panel sterowania programu do akwizycji danych silnika. Dzięki temu znacznie łatwiejszy do zrealizowania staje się proces sterowania sztywnością pneumatycznej sprężyny. Dopóki wypadkowa siła pochodząca od ciśnienia w cylindrze i ciśnienia w dolnym zbiorniku (6) jest mniejsza od siły sprężyny gazowej nad dodatkowym tłokiem, dopóty tłok znajduje się w najniższym, zerowym, położeniu i stopień sprężania silnika wynosi 17 . Gdy ciśnienie w cylindrze wzrośnie na tyle, by pokonać napięcie wstępne sprężyny, tłok unosi się, zmniejszając stopień sprężania do $8 \mathrm{w}$ górnej skrajnej pozycji. Dodatkowy tłok spełnia rolę regulatora maksymalnego ciśnienia w cylindrze i w każdym cyklu jego położenie zmienia się samoczynnie, dopasowując stopień sprężania do bieżącego obciążenia silnika. Przez odpowiednią regulację ciśnienia i objętości w zbiorniku (1) możliwa jest zmiana zakresu samoczynnej regulacji stopnia sprężania oraz odpowiednie skoordynowanie faz ruchu tłoka dodatkowego z cyklem pracy silnika dla danej prędkości obrotowej i obciążenia.

Spodziewana sprawność silnika z tak zaprojektowaną i wyposażoną głowicą powinna być wysoka, ze względu na podwyższenie stopnia sprężania oraz odzyskiwanie części energii pochłoniętej przez PAE podczas procesu spalania. Sprężanie powietrza $\mathrm{w}$ zbiorniku ponad dodatkowym tłokiem podczas jego ruchu w górę powoduje akumulację energii obarczoną pewnymi stratami. Energia zgromadzona w zbiorniku jest oddawana do gazów spalinowych w cylindrze w czasie suwu pracy, gdy tłok dodatkowy opada i powraca do dolnego położenia. Podczas powrotu dodatkowego tłoka w cylindrze głównym wysokie ciśnienie utrzymuje się dłużej niż w typowym silniku ZI, choć ciśnienie maksymalne zostaje ograniczone. Przy przymkniętej przepustnicy, gdy do cylindra dostaje się mała ilość mieszanki, silnik podczas pracy przy dużym stopniu sprężania dodatkowo generuje wyższe ciśnienia maksymalne w cylindrze, co również wpływa na jego sprawność.

\section{Program i cel badań}

Badania prototypowego silnika $\mathrm{z}$ tłokiem dodatkowym w głowicy wykonano w hamowni silnikowej Katedry Pojazdów i Podstaw Budowy Maszyn Politechniki Łódzkiej na stanowisku dynamometrycznym z pomiarem momentu obrotowego i zużycia paliwa [3, 7]. Cykl silnika analizowano na podstawie pomiaru ciśnienia $\mathrm{w}$ cylindrze oraz położenia dodatkowego tłoka w głowicy. Do pomiaru ciśnienia zastosowano przetwornik ciśnienia AVL 12QP 300cv wraz z układem wzmacniacza. Ruch thoka dodatkowego mierzono za pomocą laserowego przetwornika przemieszczenia Keyence LK-G152 wraz ze sterownikiem. Do rejestracji danych użyto karty akwizycji National Instruments NI USB 6210. Częstotliwość próbkowania sygnałów pomiarowych ograniczono do $30 \mathrm{kHz}$ ze względu na możliwości przetwornika przemieszczenia. Przebieg pomiaru i rejestrację danych 
was supervised with LabView-based software. The control panel has been shown in Fig. 3.

The tests were conducted for three engine speeds and three part loads corresponding to the throttle opening of $\alpha_{\mathrm{p}}=6^{\circ}, \alpha_{\mathrm{p}}=12^{\circ}$ and $\alpha_{\mathrm{p}}=18^{\circ}$. Pressure $\mathrm{p}_{\mathrm{g}}$ and volume $\mathrm{V}_{\mathrm{g}}$ of the upper PEA tank was also modified, assuming: $\mathrm{p}_{\mathrm{g}}=9 \mathrm{bar}$ and $\mathrm{p}_{\mathrm{g}}=11$ bar and $\mathrm{V}_{\mathrm{g}}=427 \mathrm{~cm}^{3}, \mathrm{~V}_{\mathrm{g}}=770 \mathrm{~cm}^{3}$ and $\mathrm{V}_{\mathrm{g}}=$ $=1170 \mathrm{~cm}^{3}$ respectively. The pressure under the crown of the additional piston was constant and amounted to $\mathrm{p}_{\mathrm{d}}=$ $=2$ bar. The results of the measurements were adjusted to normal conditions [9] to allow their comparison. Full plan of the research has been presented in Table 1 .

Figure 4 presents a selected course of the measured pressure inside the cylinder together with the movement of the additional piston. Both courses are expressed as a function of relative change of volume generated exclusively by the movement of the main piston connected with the crankshaft with a connecting rod. From the analysis of the image it results that the additional piston lifting to approximately $2.2 \mathrm{~mm}$ at the end of the compression stroke extended the combustion chamber and at the same time limited the increment of maximum pressure during the combustion to $4 \mathrm{MPa}$ by moving up as high as $17 \mathrm{~mm}$. The piston plays a role of the maximum pressure regulator inside the cylinder maintaining it on the level of the conventional 126A1.076/E engine of the compression ratio of 8 . When the piston moves down, a part is visible where the pressure inside the cylinder is kept almost on a constant level, hence, at the end of the combustion process, the exhaust gas recovers some of the energy previously accumulated in the upper PEA tank under the crown of the additional piston. nadzorowano za pomocą oprogramowania wykonanego w pakiecie LabView. Panel obsługi i sterowania pomiarem przedstawiono na rys. 3 .

Badania prowadzono przy trzech prędkościach obrotowych i trzech częściowych obciążeniach odpowiadających uchyleniu przepustnicy $\alpha_{\mathrm{p}}=6^{\circ}, \alpha_{\mathrm{p}}=12^{\circ}$ oraz $\alpha_{\mathrm{p}}=18^{\circ}$. Zmieniano także ciśnienie $\mathrm{p}_{\mathrm{g}}$ i objętość $\mathrm{V}_{\mathrm{g}}$ górnego zbiornika PAE, przyjmując odpowiednio: $\mathrm{p}_{\mathrm{g}}=9$ bar i $\mathrm{p}_{\mathrm{g}}=11$ bar oraz $\mathrm{V}_{\mathrm{g}}=427 \mathrm{~cm}^{3}, \mathrm{~V}_{\mathrm{g}}=770 \mathrm{~cm}^{3} \mathrm{i} \mathrm{V}_{\mathrm{g}}=1170 \mathrm{~cm}^{3}$. Ciśnienie pod kielichem tłoka dodatkowego było stałe $\mathrm{i}$ wynosiło $\mathrm{p}_{\mathrm{d}}=$ $=2$ bar. Wyniki pomiarów korygowano do warunków normalnych [9], aby możliwe było ich porównanie. Pełen program przeprowadzonych badań podano w tabeli 1 .

Na rysunku 4 przedstawiono wybrany przebieg zmierzonego ciśnienia w cylindrze wraz z przebiegiem ruchu dodatkowego tłoka. Oba przebiegi pokazane są w funkcji względnej zmiany objętości wywołanej wyłącznie ruchem tłoka głównego, związanego z korbowodem i wałem korbowym silnika. Z analizy rysunku wynika, że tłok dodatkowy, który uniósł się do około 2,2 mm w końcu suwu sprężania samoczynnie powiększył komorę spalania. Ograniczył jednocześnie wzrost ciśnienia maksymalnego w czasie spalania do $4 \mathrm{MPa}$, unosząc się aż o $17 \mathrm{~mm}$. Tłok spełnia zatem funkcję regulatora ciśnienia maksymalnego w cylindrze, utrzymując je na poziomie ciśnienia oryginalnego silnika 126A1.076/E o stopniu sprężania 8. Przy opadaniu tłoka dodatkowego widoczny jest odcinek, w którym ciśnienie w cylindrze jest podtrzymywane prawie na stałym poziomie, a więc pod koniec procesu spalania gazy spalinowe odzyskują część energii zakumulowanej wcześniej w górnym zbiorniku PAE ponad kielichem dodatkowego tłoka. Akumu-

Table 1. Conditions of the measurements

Tabela 1. Warunki pomiarów stanowiskowych prototypowego silnika

\begin{tabular}{|c|c|c|c|c|}
\hline $\begin{array}{l}\text { Volume of the upper tank/ } \\
\text { objętość górnego zbiornika }\end{array}$ & $\begin{array}{l}\text { Pressure of the upper tank/ } \\
\text { ciśnienie górnego zbiornika }\end{array}$ & $\begin{array}{l}\text { Pressure of the lower tank/ } \\
\text { ciśnienie dolnego zbiornika }\end{array}$ & $\begin{array}{l}\text { Throttle position/ } \\
\text { położenie przepustnicy }\end{array}$ & $\begin{array}{c}\text { Engine speed/ } \\
\text { prędkość obrotowa }\end{array}$ \\
\hline$\left[\mathrm{cm}^{3}\right]$ & [bar] & [bar] & {$[\%]$} & {$[\mathrm{rpm}]$} \\
\hline \multirow[t]{6}{*}{427} & \multirow[t]{3}{*}{9} & \multirow[t]{3}{*}{2} & 6 & $1000,1500,2000$ \\
\hline & & & 12 & $1000,1500,2000$ \\
\hline & & & 18 & $1000,1500,2000$ \\
\hline & \multirow[t]{3}{*}{11} & \multirow[t]{3}{*}{2} & 6 & $1000,1500,2000$ \\
\hline & & & 12 & $1000,1500,2000$ \\
\hline & & & 18 & $1000,1500,2000$ \\
\hline \multirow[t]{6}{*}{770} & \multirow[t]{3}{*}{9} & \multirow[t]{3}{*}{2} & 6 & $1000,1500,2000$ \\
\hline & & & 12 & $1000,1500,2000$ \\
\hline & & & 18 & $1000,1500,2000$ \\
\hline & \multirow[t]{3}{*}{11} & \multirow[t]{3}{*}{2} & 6 & $1000,1500,2000$ \\
\hline & & & 12 & $1000,1500,2000$ \\
\hline & & & 18 & $1000,1500,2000$ \\
\hline \multirow[t]{6}{*}{1170} & \multirow[t]{3}{*}{9} & \multirow[t]{3}{*}{2} & 6 & $1000,1500,2000$ \\
\hline & & & 12 & $1000,1500,2000$ \\
\hline & & & 18 & $1000,1500,2000$ \\
\hline & \multirow[t]{3}{*}{11} & \multirow[t]{3}{*}{2} & 6 & $1000,1500,2000$ \\
\hline & & & 12 & $1000,1500,2000$ \\
\hline & & & 18 & $1000,1500,2000$ \\
\hline
\end{tabular}


The accumulation of energy is done during the upward movement of the additional piston. It is the process of compressing of the PEA spring, i.e. pressure increment in the upper tank above the crown of the additional piston. The downward movement of the piston results in a transfer of the energy from PEA to the exhaust gas inside the cylinder, which enables a recovery of the work (energy recuperation that was earlier accumulated in the upper tank above the crown of the piston during the upward movement). This is not an ideal thermodynamic process and it generates losses. PEA consumes more energy than it can release. The results of the measurements should indicate the displacement of the additional piston corresponding to the changes in the compression ratio for which it could be beneficial (increase in the overall engine efficiency). The results should also confirm whether the energy accumulated in PEA is returned with the exhaust valves still closed. The inertia of

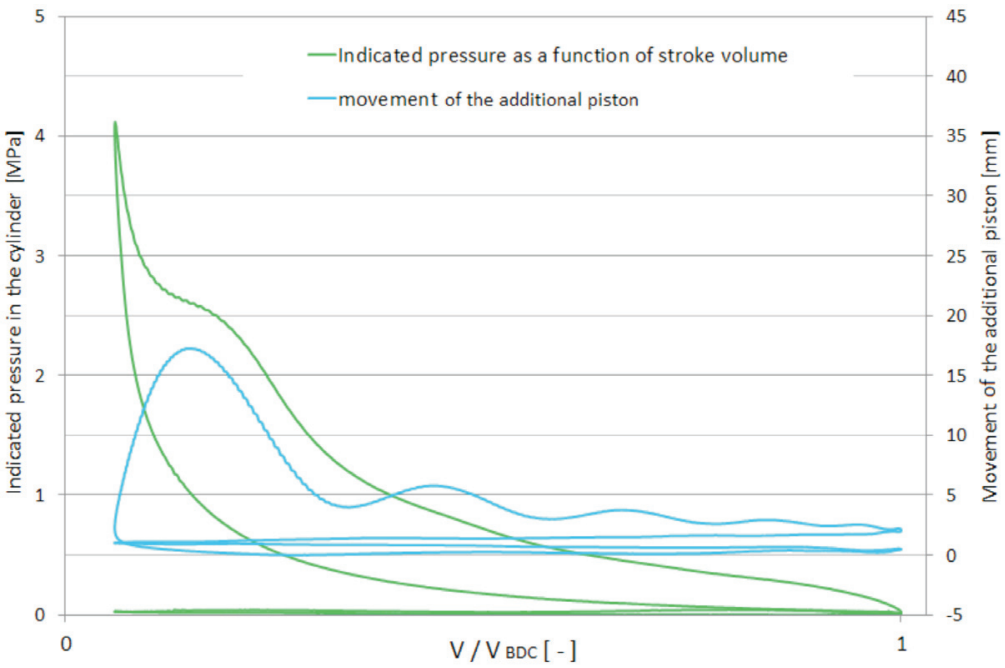

Fig. 4. Sample p-V graph of the actual indicated pressure and movement of the additional piston in the tested prototype VCR engine

Rys. 4. Przykładowy wykres p-V rzeczywistego przebiegu ciśnienia indykowanego i ruchu dodakowego tłoka w badanym prototypowym silniku VCR

lacja energii odbywa się podczas ruchu dodatkowego tłoka ku górze. Jest to proces ściskania sprężyny pneumatycznej PAE, tzn. narastania ciśnienia w górnym zbiorniku ponad kielichem dodatkowego tłoka. Ruch tłoka w dół powoduje przekazanie energii z PAE do gazów spalinowych w cylindrze, dzięki czemu możliwe jest odzyskanie pracy - rekuperacja energii, zakumulowanej wcześniej w górnym zbiorniku ponad kielichem tłoka dodatkowego przy jego unoszeniu. Nie jest to idealny proces termodynamiczny i jest obarczony stratami. PAE pobiera więcej energii niż może oddać. Wyniki pomiarów powinny wskazać zakres skoku dodatkowego tłoka odpowiadający zmianom stopnia sprężania, w którym osiągane są korzyści, czyli wzrost sprawności ogólnej silnika. Powinny też potwierdzić, czy energia zmagazynowana w PAE jest oddawana jeszcze przy zamkniętych zaworach wydechowych. Bezwładność tłoka dodatkowego wydłuża czas reakcji PAE na zmiany ciśnienia w komorze spalania, co powoduje, że proces regulacji maksymalnego ciśnienia i odzyskiwania energii, po przekroczeniu pewnej prędkości obrotowej, może rozsynchronizować się z cyklem silnika, dając gorsze efekty energetyczne. Celem badań stało się sprawdzenie i ocena możliwości poprawnej i stabilnej pracy prototypowego silnika przy częściowym obciążeniu i umiarkowanych prędkościach obrotowych silnika oraz dobór objętości i ciśnienia PAE, zapewniających korzyści wynikające z adaptacyjnych zmian stopnia sprężania.

\section{Wyniki pomiarów}

$\mathrm{Na}$ rysunku 5 przedstawiono przykład wielokrotnego wykresu przebiegu ciśnienia w cylindrze dla wybranego punktu pomiarowego. Widoczny jest stabilizujący wpływ tło-
Fig. 5. Tracing of the indicated pressure and movement of the additional piston in the tested engine $\left(\omega_{\mathrm{s}}=2000 \mathrm{rpm}, \alpha_{\mathrm{p}}=18^{\circ}\right)$

Rys. 5. Wykres wielokrotny ciśnienia indykowanego i ruchu dodatkowego tłoka w badanym silniku $\left(\omega_{s}=2000 \mathrm{obr} / \mathrm{min}, \alpha_{p}=18^{\circ}\right)$ 
on the maximum pressure inside the cylinder is clearly visible. The displacement of the additional piston is greater in cycles in which the maximum cylinder pressure is higher (clearly exceeds $4 \mathrm{MPa}$ ) and smaller in cycles of lower maximum pressure. Hence, during the engine operation, the difference between subsequent cycles was reduced. The PEA system with the additional piston in the prototype engine serves the assumed purpose of an in-cylinder exhaust gas pressure regulator. The investigations have confirmed

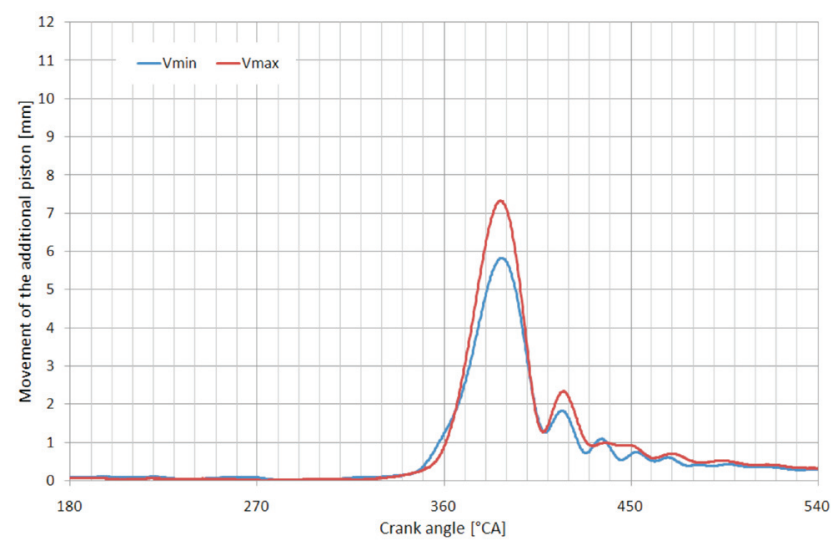

Fig. 6. Movement of the additional piston depending on the volume of the upper PEA tank: $\omega_{\mathrm{s}}=1500 \mathrm{rpm}, \alpha_{\mathrm{p}}=12^{\circ}, \mathrm{p}_{\mathrm{g}}=9 \mathrm{bar}$

Rys. 6. Ruch ttoka dodatkowego w zależności od objętości górnego zbiornika PAE dla: $\omega_{s}=1500 \mathrm{obr} / \mathrm{min}, \alpha_{p}=12^{\circ}, p_{g}=9 \mathrm{bar}$

the expectations of the correctness of operation of the PEA system applied in the engine. The additional piston moves in each engine cycle without the need to apply additional external synchronization.

Figures 6 and 7 present the influence of pressure and volume of the upper tank on the movement of the additional piston. Phase shift of the start of the piston lift against TDC $\left(360^{\circ}\right.$ C.A.) depends mainly on the pressure in the upper PEA tank (initial tension). As per relation (1), showing the adiabatic pneumatic spring, the change of volume may more significantly influence the hardness of the spring than the pressure but only if the initial tank volume is sufficiently small:

$$
\mathrm{k}_{\mathrm{g}}=\frac{\mathrm{m} \cdot \mathrm{p}_{\mathrm{g} 0} \cdot \mathrm{A}_{\mathrm{g}}^{2}}{\mathrm{~V}_{\mathrm{g}}}\left[\frac{1}{1-\frac{\mathrm{A}_{\mathrm{g}}}{\mathrm{V}_{\mathrm{g}}} \cdot \mathrm{x}}\right]^{\mathrm{m}+1}
$$

For the tested engine the volume of the upper PEA tank was large, which resulted from the presented design. This forced the application of high feed pressures inside the tank. An increase in the pressure inside the upper PEA tank is tantamount with an increase in the initial tension of the pneumatic spring. From the recorded tracings it results that, at the pressure of 9 bar, the additional piston displacement is approx. $11 \mathrm{~mm}$, while after the pressure grows to 11 bar, the displacement drops by $4 \mathrm{~mm}$ to slightly more than ka dodatkowego w głowicy silnika na maksymalne ciśnienie w cylindrze. Skok tłoka dodatkowego jest bowiem większy w cyklach, w których maksymalne ciśnienie w cylindrze jest większe - wyraźnie przekracza $4 \mathrm{MPa}$, i mniejszy w cyklach o mniejszym ciśnieniu maksymalnym. W związku z tym podczas pracy silnika uzyskano zmniejszoną różnicę między kolejnymi cyklami. Układ PAE z tłokiem dodatkowym w prototypowym silniku spełnia założoną funkcję regulatora ciśnienia gazów spalinowych w cylindrze. Badania potwier-

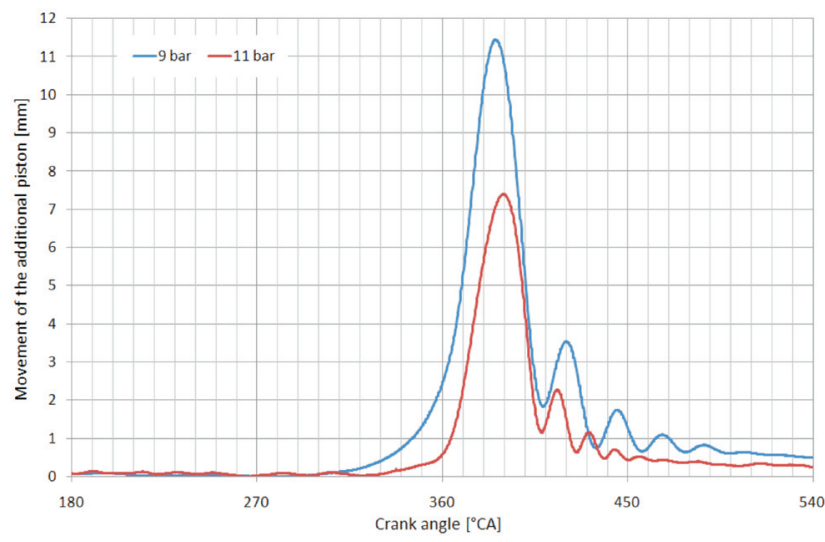

Fig. 7. Movement of the additional piston depending on the pressure of the upper PEA tank: $\omega_{\mathrm{s}}=1500 \mathrm{rpm}, \alpha_{\mathrm{p}}=18^{\circ}, \mathrm{V}_{\mathrm{g}}=427 \mathrm{~cm}^{3}$

Rys. 7. Ruch tłoka dodatkowego w zależności ciśnienia zasilania górnego zbiornika PAE dla: $\omega_{s}=1500 \mathrm{obr} / \mathrm{min}, \alpha_{p}=18^{\circ}, V_{g}=427 \mathrm{~cm}^{3}$

dziły oczekiwania dotyczące poprawności działania zastosowanego w silniku układu PAE. Dodatkowy tłok wykonuje ruch w każdym cyklu pracy silnika bez potrzeby stosowania dodatkowej zewnętrznej synchronizacji.

Na rysunkach 6 oraz 7 przedstawiono wpływ ciśnienia i objętości górnego zbiornika na ruch dodatkowego tłoka. Przesunięcie fazowe początku wzniosu tłoka względem GMP silnika $\left(360^{\circ} \mathrm{OWK}\right)$ zależy natomiast przede wszystkim od ciśnienia w górnym zbiorniku PAE (napięcia wstępnego). Zgodnie z zależnością (1), przedstawiającą adiabatyczną sprężynę pneumatyczną, zmiana objętości może silniej niż ciśnienie wpływać na sztywność sprężyny, ale tylko wówczas, gdy początkowa objętość zbiornika jest odpowiednio mała - wzór (1).

Dla badanego silnika objętość górnego zbiornika PAE była duża, co wynikało z konstrukcji. Wymuszało to stosowanie wysokich ciśnień zasilania w zbiornika. Wzrost ciśnienia w górnym zbiorniku PAE jest równoznaczny z przyrostem napięcia wstępnego sprężyny pneumatycznej. Z zarejestrowanych przebiegów wynika, że przy ciśnieniu 9 bar skok tłoka dodatkowego wynosi około $11 \mathrm{~mm}$, natomiast po wzroście ciśnienia do 11 bar skok spada o $4 \mathrm{~mm}$ do nieco ponad $7 \mathrm{~mm}$. Skok tłoka przy zmianie objętości od największej do najmniejszej zmienia się natomiast tylko o około 1,4 mm. Przy zastosowanej konstrukcji sprężyny pneumatycznej regulacja jej sztywności i wpływu na fazę początku unoszenia tłoka dodatkowego możliwa jest tylko przez zmianę ciśnienia. Warto zauważyć, że ruch tłoka związany z procesem opadania powinien zakończyć się przed 
$7 \mathrm{~mm}$. The piston displacement at a volume change, from the greatest to the smallest, changes only by approx. $1.4 \mathrm{~mm}$. In the presented design of the pneumatic spring, the adjustment of its hardness and influence on the start of the lift of the additional piston is possible through the change of pressure only. It is noteworthy that the downward movement of the piston should end before the opening of the exhaust valves. Finishing of the process would be optimum before $450^{\circ}$ C.A. At this position of the crank, the changes in the cylinder displacement are the smallest. External work will have small increments even if the pressure inside the cylinder is high. The initial tension and the hardness of the upper spring

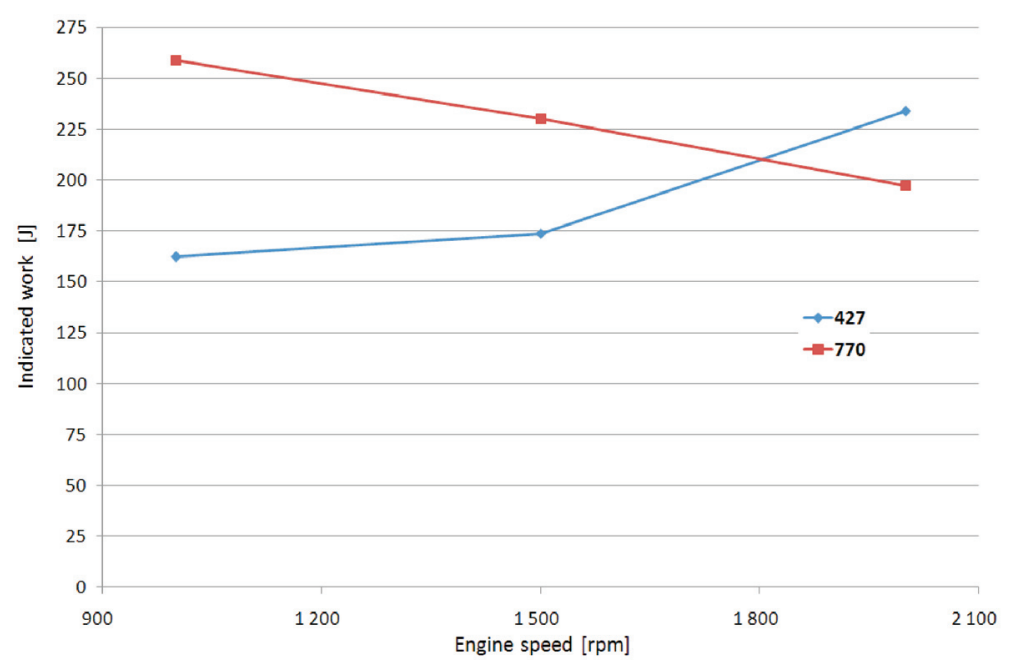

Fig. 8. The influence of the volume of the upper PEA tank on the indicated work of a cycle depending on the engine speed: $\alpha_{\mathrm{p}}=12^{\circ}, \mathrm{p}_{\mathrm{g}}=11 \mathrm{bar}$

Rys. 8. Wpływ objętości górnego zbiornika PAE na pracę indykowana cyklu $w$ zależności od prędkości obrotowej silnika dla: $\alpha_{p}=12^{\circ}, p_{g}=11$ bar

must then be high. This results in an increase in the pressure of the upper PEA tank with a simultaneous reduction of its volume for a given point of work.

The dependence of the indicated work on the volume of the upper PEA tank above the crown of the additional piston for varied engine speeds has been presented in Fig. 8. The final explanation of the phenomenon requires further research, but from the presented graph we may still read that at lower speeds greater values of work were obtained for greater volume -770 $\mathrm{cm}^{3}$ and at higher engine speeds - for smaller volume $-427 \mathrm{~cm}^{3}$. While reducing the volume, the characteristics of the spring hardness changes, which limits the movement of the additional piston. The influence of the volume on the mean indicated work for varied engine loads, as shown in Fig. 9, indicates the smallest volume of 427 $\mathrm{cm}^{3}$ as the one that allows obtaining the greatest values of work, hence greater indicated pressure. This results in an approximation of the work cycle to the Otto cycle with high compression otwarciem zaworów wydechowych. Najbardziej optymalne byłoby zakończenie procesu przed $450^{\circ} \mathrm{OWK}$. W takim położeniu korby zmiany objętości skokowej cylindra są najmniejsze. Praca zewnętrzna będzie osiągać małe przyrosty nawet wtedy, gdy ciśnienie w cylindrze będzie wysokie. Napięcie wstępne i sztywność górnej sprężyny muszą zatem być wysokie. Powoduje to zwiększenie ciśnienia w górnym zbiorniku PAE z jednoczesnym zmniejszeniem jego objętości dla danego punktu pracy.

Zależność pracy indykowanej od objętości górnego zbiornika PAE ponad kielichem dodatkowego tłoka dla różnych prędkości obrotowych silnika przedstawiono na rys. 8 . Jednoznaczne wyjaśnienie tego wymaga przeprowadzenia dodatkowych badań, ale z przedstawionego wykresu można jednak odczytać, że przy mniejszych prędkościach większe wartości pracy otrzymano dla większej objętości $-770 \mathrm{~cm}^{3}$, a przy większych prędkościach - dla mniejszej objętości $-427 \mathrm{~cm}^{3}$. Podczas zmniejszania objętości zmienia się charakterystyka sztywności sprężyny, co zmniejsza możliwość ruchu dodatkowego tłoka. Pokazany na rys. 9 wpływ objętości na średnią pracę indykowaną dla różnego obciążenia silnika wskazuje najmniejszą objętość - $427 \mathrm{~cm}^{3}$ jako tę, która pozwala uzyskać największe wartości pracy, a zatem większe ciśnienia indykowane. To powoduje zbliżenie cyklu pracy do obiegu Otto z dużym stopniem sprężania, a zatem poprawę sprawności procesu termodynamicznego w silniku.

Na rysunku 10 pokazano wpływ prędkości obrotowej silnika na przesunięcie fazowe ruchu tłoka dodatkowego względem cyklu pracy silnika. Dla obu prędkości ruch tłoka rozpoczynał się w tej samej chwili cyklu, lecz przy większej prędkości obrotowej (1500 obr/min) zaobserwowano większe niż przy $1100 \mathrm{obr} / \mathrm{min}$ opóźnienie dodatkowego tłoka względem obrotu wału korbowego. Przy zmianie

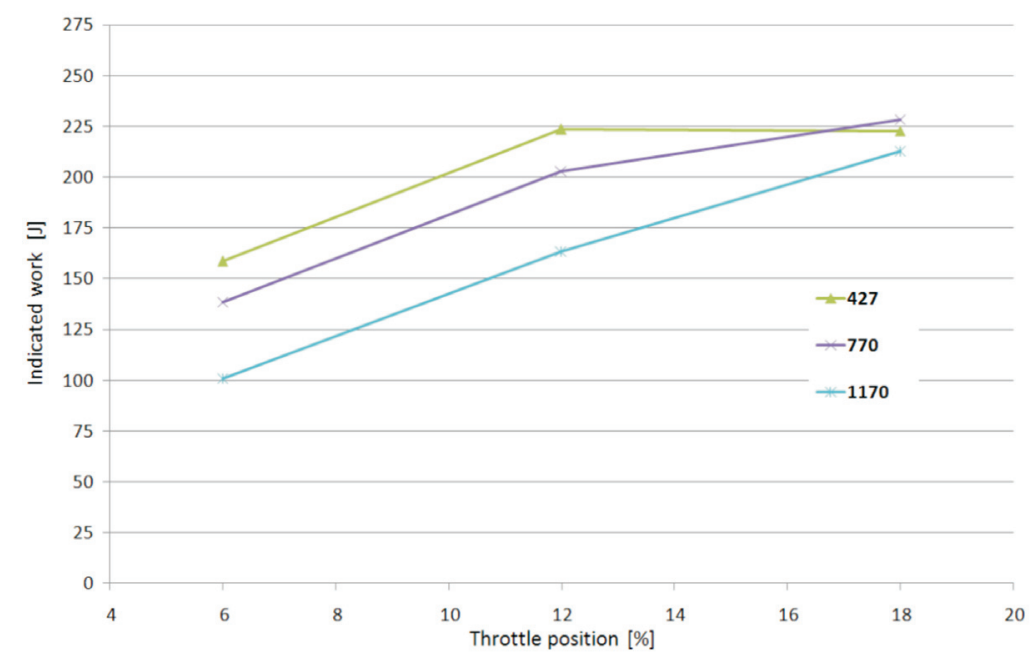

Fig. 9. The influence of the volume of the upper PEA tank on the indicated work of a cycle depending on the engine load: $\omega_{\mathrm{s}}=1500 \mathrm{rpm}, \mathrm{p}_{\mathrm{g}}=9 \mathrm{bar}$

Rys. 9. Wpływ objętości górnego zbiornika PAE na pracę indykowana cyklu w zależności od obciązenia silnika dla: $\omega_{s}=1500 \mathrm{obr} / \mathrm{min}, p_{g}=9 \mathrm{bar}$ 
ratio, thus an improvement of the efficiency of the engine thermodynamic process.

Figure 10 shows the influence of the engine speed on the phase shift of the additional piston against the engine work cycle. For both speeds the piston movement began at the same moment of the cycle but at a higher engine speed (1500 rpm) a greater delay of the movement of the additional

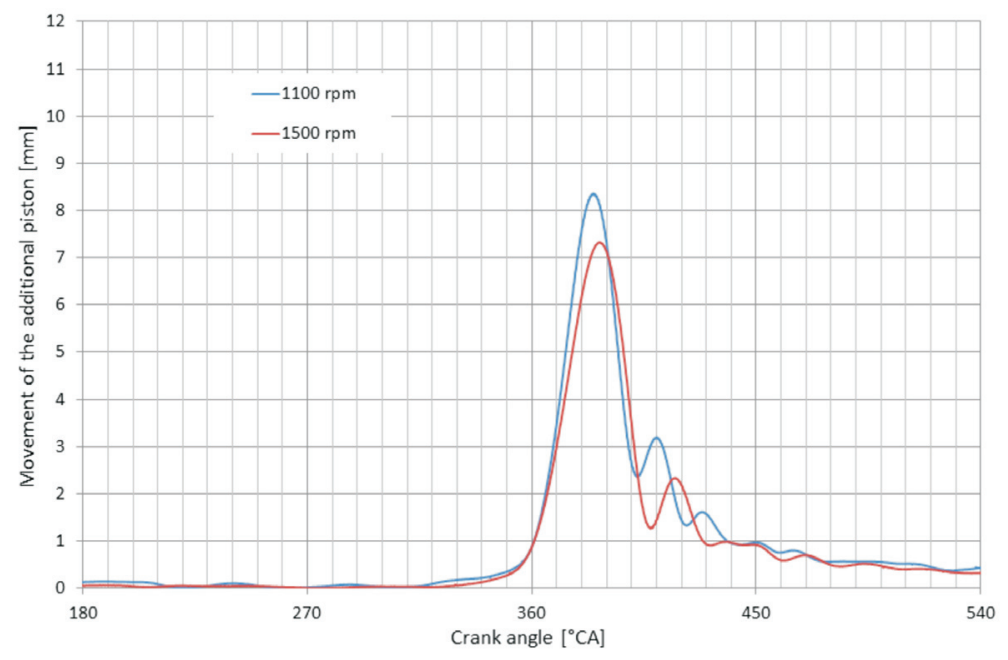

Fig. 10. The influence of the engine speed on the movement of the additional piston: $\alpha_{\mathrm{p}}=12^{\circ}, \mathrm{p}_{\mathrm{g}}=9$ bar, $\mathrm{V}_{\mathrm{g}}=1170 \mathrm{~cm}^{3}$

Rys. 10. Wykres wptywu prędkości obrotowej silnika na ruch dodatkowego tłoka PAE dla: $\alpha_{p}=12^{\circ}, p_{g}=9$ bar, $V_{g}=1170 \mathrm{~cm}^{3}$

piston against the crankshaft revolution than for $1100 \mathrm{rpm}$ was observed. With a change of speed by as little as $400 \mathrm{rpm}$ the position of the highest piston lift displaced by as much as $5^{\circ}$ C.A. towards the end of the exhaust stroke. Additionally, because of inertia, the additional piston was not capable of catching up the increment of pressure during combustion and its highest lift was reduced as the engine speed increased. The inertia limited the proper operation of the engine up to above $2000 \mathrm{rpm}$. Above these speeds, the movement of the additional piston was delayed so much that it did not sufficiently limit the pressure increment inside the cylinder and moved down too late to recover the energy accumulated in the PEA prior to the opening of the exhaust valve. As results from the analysis of Fig. 4, an approximation to the cycle similar to the Sabathe cycle has not been reached. In the Sabathe cycle for some time inside the cylinder maximum pressure is maintained.

When evaluating the efficiency of the PEA system, the authors used the analysis of the work performed by the gas inside the cylinder taking into account the change of volume triggered by the movement of the additional piston. Figure 11 shows the volumes analyzed during the work cycle. The greatest is the total instantaneous volume, constituting prędkości zaledwie o $400 \mathrm{obr} / \mathrm{min}$ położenie największego wzniosu tłoka dodatkowego przesunęło się aż o $5^{\circ} \mathrm{OWK}$ w stronę końca suwu rozprężania. Ponadto na skutek bezwładności dodatkowy tłok nie jest w stanie nadążać za wzrostem ciśnienia przy spalaniu i jego największy wznios maleje ze wzrostem prędkości obrotowej silnika. Bezwładność ograniczała prawidłowe działanie silnika do nieco ponad 2000 obr/min. Powyżej tej prędkości ruch tłoka dodatkowego opóźnia się na tyle, że nie ogranicza wystarczająco przyrostu ciśnienia w cylindrze i opada zbyt późno, by przed otwarciem zaworu wylotowego odzyskać energię zakumulowaną w PAE. Jak wynika $z$ analizy rys. 4 , nie zbliżono się do cyklu podobnego do obiegu Sabathe, gdzie przez pewien czas w cylindrze podtrzymywane jest ciśnienie maksymalne.

Przy ocenie sprawności PAE posłużono się analizą pracy wykonanej przez gaz w cylindrze z uwzględnieniem zmiany objętości wywołanej ruchem tłoka dodatkowego. Na rysunku 11 wyróżniono rozpatrywane, podczas cyklu pracy, objętości. Największą z nich jest chwilowa objętość całkowita, stanowiąca zawsze sumę poszczególnych objętości. Na rysunku przyjęto, że w GMP dodatkowy tłok pozostaje nieruchomy. W rzeczywistości takie zachowanie się układu występuje jedynie przy bardzo małych obciążeniach i generuje największy stopień sprężania.

Ocenę sprawności przeprowadzono na podstawie pomiarów ciśnienia w cylindrze i ruchu tłoka dodatkowego. Na rysunku 12 pokazano przebiegi pracy indykowanej gazu w całkowitej objętości spalania z podziałem na pracę wykonaną przez tłok główny, związany z układem korbowym silnika, oraz pracę tłoka dodatkowego PAE. W badanej konstrukcji nie cała energia pochłaniania w zbiorniku PAE podczas unoszenia dodatkowego tłoka odzyskiwana jest

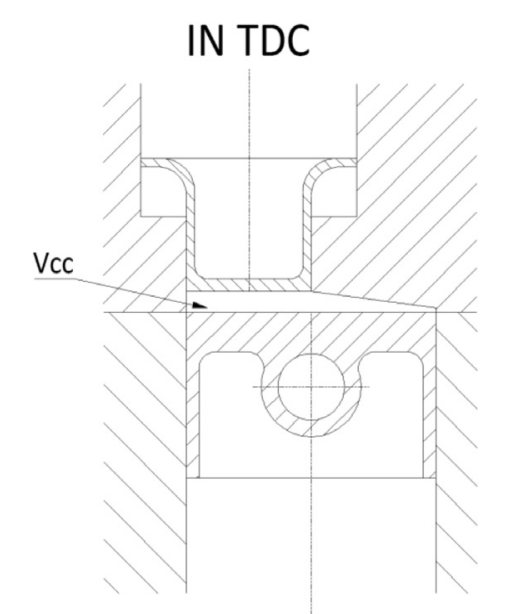

Fig. 11. The discussed volumes during the engine cycle: $\mathrm{V}_{c c}$ - combustion chamber volume, $\mathrm{V}_{\mathrm{s}}$ - stroke volume, $\mathrm{V}_{\mathrm{ap}}$ - volume caused by the movement of the additional piston

Rys. 11. Rozpatrywane objętości podczas cyklu pracy silnika: $V_{c c}$-objętość komory spalania, $V_{s}$-objętość skokowa, $V_{a p}$-objętość wywołana ruchem dodatkowego tłoka 


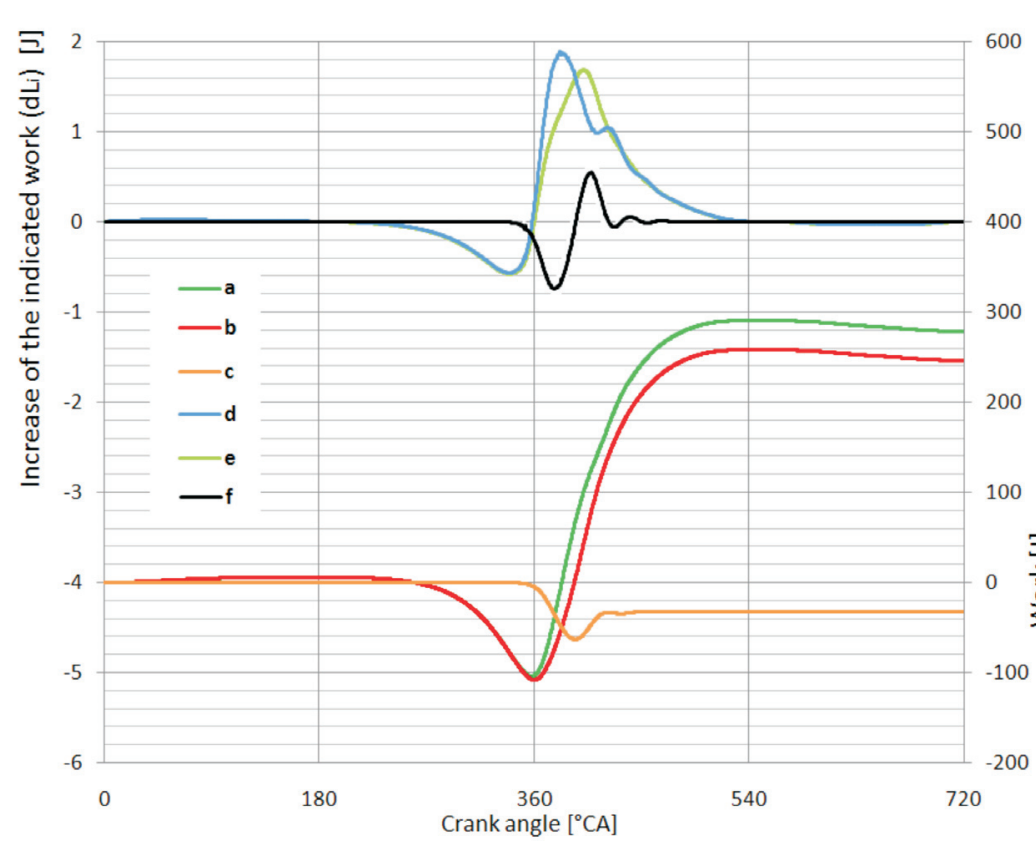

Fig. 12. Indicated work and its increments in the tested engine for: $\mathrm{M}_{\mathrm{N}}=27.4 \mathrm{~N} \cdot \mathrm{m}$, $\omega_{\mathrm{s}}=1490 \mathrm{rpm}, \alpha_{\mathrm{p}}=18^{\circ}, \mathrm{p}_{\mathrm{I}}=0.75 \mathrm{MPa}$; a - work of gas in the total volume of the combustion chamber, $\mathrm{b}$ - work transferred to the piston-crank system, $\mathrm{c}$ - work of the additional piston, $\mathrm{d}$ - work increment in the total volume of the combustion chamber, e - work increment in the stroke volume, $\mathrm{f}$ - work increment in the additional volume resulting from the movement of the additional piston

Rys. 12. Przebieg pracy indykowanej i jej przyrostów w badanym silniku dla: $M_{N}=27,4 \mathrm{~N} \cdot \mathrm{m}, \omega_{s}=1490 \mathrm{obr} / \mathrm{min}, \alpha_{p}=18^{\circ}, p_{i}=0,75 \mathrm{MPa} ;$ a - praca indykowana gazu $w$ całkowitej objętości komory spalania, b - praca indykowana układu tłokowo-korbowego, $c$ - praca indykowana tłoka dodatkowego, d-przyrost pracy w calkowitej objętości, $e$ - przyrost pracy w objętości skokowej, f-przyrost pracy $w$ dodatkowej objętości wynikajacej z ruchu dodatkowego ttoka

the sum of individual volumes. In the figure, it has been assumed that, at TDC, the additional piston remains stationary. In a real engine, such a situation in the system occurs only at very small loads and generates the highest compression ratio.

The assessment of the efficiency was performed based on the measurement of the in-cylinder pressure and the movement of the additional piston. Figure 12 shows the indicated work of the gas in the total combustion volume distinguishing the main piston (engine crank system) and the additional piston (PEA). In the tested design, not all the energy consumed by the PEA tank (when the piston moves upwards) is recovered when the additional piston moves downward. Curve $b$, showing the indicated work of the main piston is below the curve of the total indicated work of the gas inside the combustion chamber. The area below the positive part of curve $f$, corresponding to work performed when the additional piston moves down, is smaller than the area of the negative part when the piston moves up and charges the PEA. Hence, curve c, showing the energy balance recovered from $P E A$ is on the negative side during both the upward and downward movement of the additional piston.

The losses in the PEA resulting from the movement of the additional piston have been shown przy jego opadaniu. Krzywa b, obrazująca przebieg pracy indykowanej tłoka głównego układu korbowego, leży bowiem poniżej krzywej a całkowitej pracy indykowanej gazu w komorze spalania. Pole pod dodatnią częścią krzywej f, odpowiadające pracy oddanej przy opadaniu dodatkowego tłoka, jest mniejsze od pola ujemnej części przy unoszeniu tłoka i ładowaniu PAE. Dlatego krzywa c, przedstawiająca bilans energii odzyskiwanej z PAE, leży po stronie ujemnej zarówno w czasie unoszenia, jak i opadania tłoka dodatkowego.

Przebieg strat w PAE wynikających z ruchu tłoka dodatkowego przedstawiono na rys. 13. Straty rosną wraz z wzniosem tłoka przy wzroście obciążenia silnika, gdy narastające ciśnienie maksymalne musi być coraz bardziej ograniczane przez PAE. Choć przy najmniejszych obciążeniach względny przyrost sprawności badanego silnika może sięgać nawet $10 \%$, to ze względu na straty wynikające z ruchu tłoka dodatkowego przy większym obciążeniu silnik o stałym stopniu sprężania może być sprawniejszy. W tabeli 2 przedstawiono wybrane, odpowiadające sobie, wyniki badań silnika przed modyfikacją i po modyfikacji. Wyniki wskazują, że silnik po modyfikacji wykazuje się porównywalną bądź lepszą sprawnością. Ponadto w każdym z punktów pomiarowych moment napędowy generowany przez silnik jest zawsze wyższy.

Na rysunku 14 przedstawiono względne spadki sprawności teoretycznej związane ze zmianą, zmniejszaniem, stopnia sprężania. Krzywa a symbolizuje spadek sprawności obiegu Otto, gdzie za wartość wyjściową 100\% przyjęto $67,8 \%$. Krzywą b oznacza względny spadek ilorazu sprawności teoretycznej obiegu Otto, odniesionej do

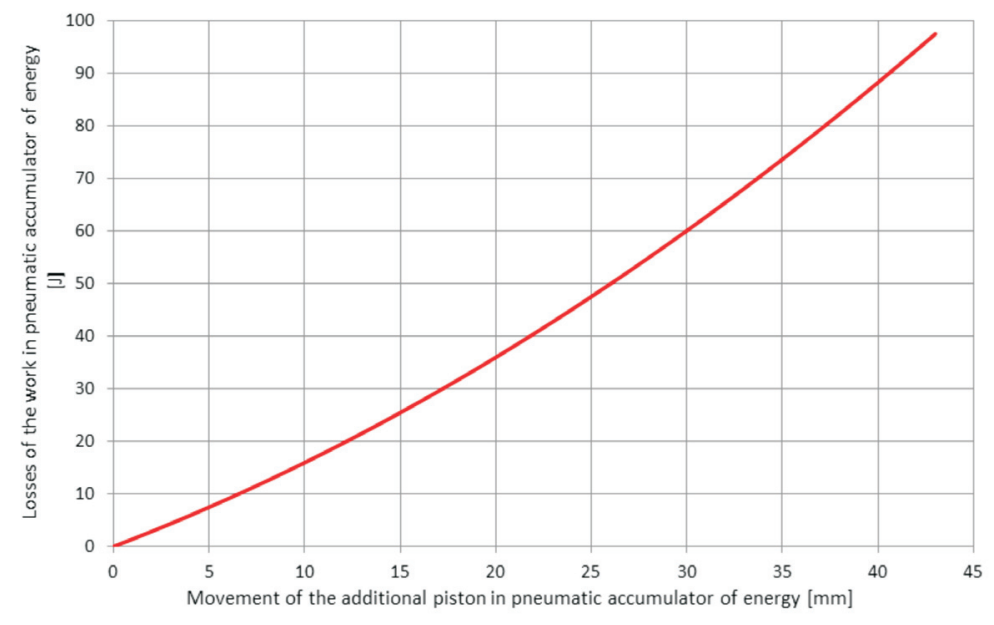

Fig. 13. Work losses in PEA as a function of additional piston movement Rys. 13. Przebieg strat w PAE prototypowego silnika w funkcji skoku dodatkowego ttoka 
Table 2. Selected results of the measurements

Tabela 2. Wyniki wybranych pomiarów

\begin{tabular}{|c|c|c|c|c|c|c|}
\hline $\begin{array}{l}\text { Volume in the upper } \\
\text { tank/objętość } \\
\text { w górnym zbiorniku }\end{array}$ & $\begin{array}{l}\text { Pressure in the upper } \\
\operatorname{tank/ciśnienie~} \\
\text { w górnym zbiorniku }\end{array}$ & $\begin{array}{l}\text { Throttle posi- } \\
\text { tion/potożenie } \\
\text { przepustnicy }\end{array}$ & $\begin{array}{c}\text { Engine speed/ } \\
\text { prędkość } \\
\text { obrotowa silnika }\end{array}$ & $\begin{array}{l}\text { Torque/ } \\
\text { moment } \\
\text { obrotowy }\end{array}$ & $\begin{array}{l}\text { Fuel consumption/ } \\
\text { zużycie paliwa }\end{array}$ & $\begin{array}{l}\text { General efficiency/ } \\
\text { sprawność ogólna }\end{array}$ \\
\hline$\left[\mathrm{cm}^{3}\right]$ & [bar] & {$[\%]$} & {$[\mathrm{rpm}]$} & {$[\mathrm{N} \cdot \mathrm{m}]$} & {$[\mathrm{g} / \mathrm{kWh}]$} & {$[\%]$} \\
\hline \multicolumn{2}{|c|}{ Unmodified engine/silnik oryginalny } & 12 & 1100 & 11.8 & 445.5 & 18.6 \\
\hline 770 & 9 & 12 & 1100 & 22.4 & 441.2 & 18.7 \\
\hline 1170 & 9 & 12 & 1100 & 20.4 & 438.2 & 18.9 \\
\hline \multicolumn{2}{|c|}{ Unmodified engine/silnik oryginalny } & 12 & 1200 & 11.5 & 503.4 & 16.4 \\
\hline 427 & 9 & 12 & 1200 & 21.7 & 420.5 & 19.7 \\
\hline 770 & 11 & 12 & 1200 & 20.7 & 462.6 & 17.9 \\
\hline \multicolumn{2}{|c|}{ Unmodified engine/silnik oryginalny } & 18 & 1200 & 15.6 & 421.9 & 19.6 \\
\hline 427 & 9 & 18 & 1200 & 26.1 & 407.5 & 20.3 \\
\hline 770 & 9 & 18 & 1200 & 26.0 & 421.1 & 19.6 \\
\hline \multicolumn{2}{|c|}{ Unmodified engine/silnik oryginalny } & 18 & 1500 & 16.5 & 405.8 & 20.4 \\
\hline 770 & 9 & 18 & 1500 & 26.3 & 380.1 & 21.7 \\
\hline 1170 & 11 & 18 & 1500 & 26.1 & 383.2 & 21.6 \\
\hline
\end{tabular}

in Fig. 13. The losses grow along with the piston lift at the increase of the engine load, when the growing maximum pressure must be increasingly limited by the PEA. Even though at small loads the relative increment of engine efficiency may reach as much as $10 \%$, an engine of constant compression ratio may turn out more efficient at greater loads due to the losses resulting from the movement of the additional piston. Table 2 presents selected corresponding results of measurements of the engine before and after the modification. The results indicate that the engine after a modification is characterized by a comparable or better efficiency. Besides, in each of the measurement points the torque generated by such an engine is always higher.

Figure 14 presents relative drops of the theoretical efficiency related to the change (reduction) of the compression ratio. Curve a shows the drop of the efficiency of the Otto cycle where the initial output value of $100 \%$ was $67.8 \%$. Curve $\mathrm{b}$ denotes relative drop of the quotient of the theoretical efficiency of the Otto cycle referred to the compression ratio and the efficiency of the PEA. This allowed determining of a new criterion related to the maximum change of the compression ratio (the displacement of the additional piston) in the tested engine. In the analysis of the graph (Fig. 14), we can see that, in order to maintain the drop of the efficiency (resulting from the active change of the compression ratio) on the level that does not exceed that resulting from the engine original design (before the application of PEA), the displacement of the additional piston may not cause a reduction of the compression ratio above 12. Further reduction of the compression ratio (as much as 10) does not make any sense. For an engine stopnia sprężania sprawności PAE. Dzięki temu możliwe stało się określenie nowego kryterium dotyczącego maksymalnej zmiany stopnia sprężania (skoku dodatkowego tłoka) w badanym silniku. Podczas analizy wykresu (rys. 14) można zauważyć, że aby spadek sprawności badanego silnika, wynikający z aktywnej zmiany stopnia sprężania, nie był większy niż ten, który wynika z konstrukcji silnika przed zastosowaniem PAE, skok dodatkowego tłoka może powodować zmniejszenie stopnia sprężania $\mathrm{w}$ badanym silniku najwyżej do 12. Dalsze zmniejszanie, nawet do 10, nie jest opłacalne i uzasadnione. Dla silnika o konstrukcyjnym stopniu sprężania 12, po zastosowaniu w jego głowicy układu PAE i zwiększeniu stopnia sprężania do $17 \mathrm{z}$ rys. 14 można odczytać, że zakres regulacji stopnia sprężania powinien wynosić od 17 do 14,5.

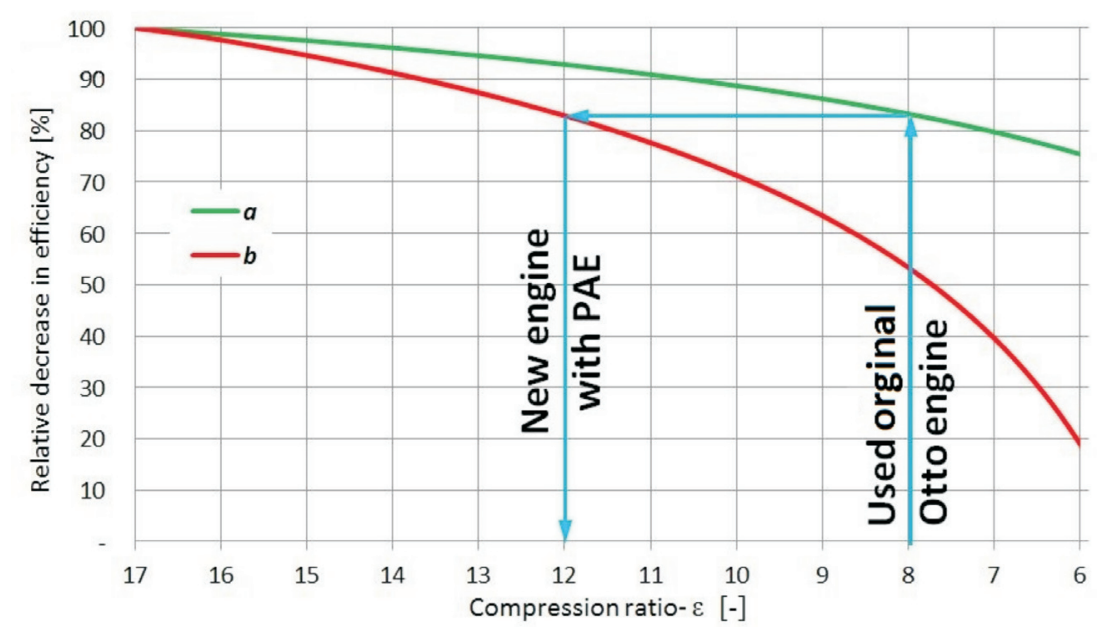

Fig. 14. Dependence of the relative decrease in the efficiency on the decrease in the compression ratio: $\mathrm{a}$ - theoretical efficiency of the Otto cycle, $\mathrm{b}$ - the quotient of the theoretical efficiency of the Otto cycle and the efficiency of the pneumatic accumulator of energy Rys. 14. Wykres zależności względnego spadku sprawności od spadku stopnia sprężania: a - sprawność teoretyczna obiegu Otto, b-iloraz sprawności teoretycznej obiegu Otto i sprawności pneumatycznego akumulatora energii 
of the original compression ratio of 12 , upon the application of PEA in the cylinder head and increasing the compression ratio to 17, we can read from Fig. 14 that the range of adjustment should be 17 to 14.5 .

\section{Conclusions}

Despite the performed research was of preliminary nature, it has shown that the prototype design of the variable compression ratio engine fitted with a pneumatic energy accumulator (PEA) with an additional piston in the cylinder head may boost the efficiency of a gasoline engine. This pertains to small engine loads and speeds only, yet the achieved increase in the efficiency (measured with the increase of mean indicated pressure and indicated work) becomes a noteworthy phenomenon. During the research, the attempts to determine a precise value of pressure and volume in the upper tank above the additional piston crown that would guarantee benefits of the use of the adaptive variable compression ratio system were unsuccessful. However, the trends in the change of these parameters construed as a change of the initial tension or the hardness of the PEA pneumatic spring have been ascertained. In order to reduce the compression ratio, the hardness should rise with the engine speed and decrease with the increasing load. The initial tension should slowly rise with the increasing load.

Further works aiming at the modification of the design of the PEA tank and the additional piston will focus on the extension of the range of speeds and loads under which the engine operation is stable and the PEA losses do not outweigh the benefits related to the increased compression ratio. The continuation of the research will focus on precise determination of the PEA system efficiency as well as a detailed analysis of thermodynamic changes occurring during the engine work cycle. This will allow a creation of a correct mathematical model of the prototype engine and will facilitate relevant further works.

\section{Wnioski}

Choć przeprowadzone badania miały charakter wstępny, to wykazały, że prototypowa konstrukcja silnika o zmiennym stopniu sprężania wyposażonego w pneumatyczny akumulator energii (PAE) z dodatkowym tłokiem $w$ głowicy może podnieść sprawność silnika ZI. Dotyczy to wprawdzie małych obciążeń i małych prędkości, lecz osiągnięty wzrost sprawności, mierzony wzrostem średniego ciśnienia indykowanego oraz pracy indykowanej, staje się wart uwagi. Podczas badań nie udało się ustalić konkretnej wartości ciśnienia i objętości w górnym zbiorniku ponad kielichem dodatkowego tłoka, tak aby zapewnić wyłącznie korzyści z pracy z adaptacyjnym stopniem sprężania. Udało się natomiast określić kierunki zmian tych parametrów rozumiane jako zmiana napięcia wstępnego bądź sztywności sprężyny pneumatycznej PAE. Sztywność powinna wzrastać wraz z obrotami silnika, a jednocześnie maleć wraz ze wzrostem obciążenia, aby zmniejszać stopień sprężania. Napięcie wstępne powinno natomiast powoli wzrastać ze wzrostem obciążenia.

Dalsze prace zmierzające do zmiany konstrukcji zbiornika PAE i dodatkowego tłoka będą miały za zadanie rozszerzenie zakresu prędkości obrotowej i obciążenia, w którym praca silnika jest stabilna i straty w PAE nie przekraczają korzyści związanych ze zwiększeniem stopnia sprężania. Kontynuacja badań będzie dotyczyła dokładnego określenia sprawności układu PAE, a także szczegółowej analizy przemian termodynamicznych zachodzących podczas cyklu pracy silnika. Pozwoli to stworzyć poprawny model matematyczny prototypowego silnika i ułatwi dalsze prace z nim związane.

\section{Nomenclature/}

VCR variable compression ratio/zmienny stopień sprężania

PEA pneumatic energy accumulator/pneumatyczny akumulator energii

$\alpha_{n} \quad$ throttle opening/otwarcie przepustnicy [\%]

$\mathrm{A}_{\mathrm{g}} \quad$ area of the additional piston on which the pressure is exerted/powierzchnia dodatkowego tłoka, na która oddziałuje ciśnienie $\left[\mathrm{m}^{2}\right]$

$\mathrm{k}_{\mathrm{g}} \quad$ hardness of the pneumatic spring of the energy accumulator/ sztywność sprężyny pneumatycznej akumulatora energii $[\mathrm{N} / \mathrm{m}]$

$\mathrm{m} \quad$ politropic exponent/wykładnik politropy [-]

$\mathrm{M}_{\mathrm{N}} \quad$ engine torque/moment napędowy silnika $[\mathrm{N} \cdot \mathrm{m}]$

$\mathrm{p}_{\mathrm{d}} \quad$ pressure in the lower PEA tank/ciśnienie $w$ dolnym zbiorniku PAE [bar]

$\mathrm{p}_{\mathrm{g}}, \mathrm{p}_{\mathrm{g} 0}$ pressure in the upper PEA tank/ciśnienie $w$ górnym zbiorniku [bar] $\mathrm{p}_{\mathrm{i}} \quad$ mean indicated pressure/średnie ciśnienie indykowane [MPa]

$\mathrm{V}_{\text {ap }} \quad$ additional volume generated following the movement of the additional piston/dodatkowa objętość powstała $w$ wyniku ruchu dodatkowego tłoka $\left[\mathrm{cm}^{3}\right]$

$\mathrm{V}_{\mathrm{cc}} \quad$ volume of the combustion chamber/objętość komory spalania $\left[\mathrm{cm}^{3}\right]$

$\mathrm{V}_{\mathrm{d}} \quad$ volume of the lower PEA tank/objętość dolnego zbiornika $P A E\left[\mathrm{~cm}^{3}\right]$

$\mathrm{V}_{\mathrm{g}}, \mathrm{V}_{\mathrm{g} 0}$ adjustable volume of the upper PEA tank/regulowana objętość górnego zbiornika PAE [ $\left.\mathrm{cm}^{3}\right]$

$\mathrm{V}_{\mathrm{s}} \quad$ cylinder displacement/objętość skokowa cylindra $\left[\mathrm{cm}^{3}\right]$

$\omega_{\mathrm{s}} \quad$ engine speed/prędkość obrotowa silnika $[\mathrm{rpm} / \mathrm{obr} / \mathrm{min}]$

$\mathrm{x}$ displacement/movement of the additional piston/przemieszczenie/ruch dodatkowego ttoka [mm] 


\section{Bibliography/Literatura}

[1] Głogowski M., A compensating arrangement for a variable compression ratio engine, International Patent Application WO 2011/023725 A2, 03.03.2011.

[2] Głogowski M., Prototyp pneumatycznego akumulatora energii (PAE) w silniku spalinowym, Łódź 2014.

[3] Głogowski M., Pawelski Z., Opis stanowiska do badań prototypu silnika z pneumatycznym akumulatorem energii, Archiwum Motoryzacji, 4/2011.

[4] Kondo T., Hirano M., A study of a variable compression ratio engine with a double piston system, International Mechanical Engineering Congress and Exposition, IMECE2008-66453, Boston 2008.

[5] Kutlar O.A., Aslan H., Calik A.T., Methods to improve efficiency of four stroke, spark ignition engines at part load, Energy Conversion and Management, 46/2005.

[6] Lotus Cars Limited, A two-stroke internal combustion engine with variable compression ratio and an exhaust port shutter and amethod of operating such an engine, International Patent Application - WO 2011/055118 A1, 12.05.2010.

[7] Łaziński P., Wpływ parametrów regulacyjnych pneumatycznego akumulatora energii na osiągi prototypowego silnika VCR, Łódź 2013.

[8] Nissan Motor, Variable Compression Ratio Internal Combustion Engine, Japan Patent Application - JP 2011001905 A, 06.01.2011.

[9] Reciprocal internal combustion engines - Performance - Part 2: Test methods, ISO 3046-2:1987.

[10] Roberts M., Benefits and challenges of variable compression ratio (VCR), Society of Automotive Engineers, Technical Paper no 2003-01-398, 2003.

Michał Głogowski, DEng. - lecturer at the Faculty of Process and Environmental Engineering of Lodz University of Technology.

Drinz. Michat Glogowski-wykladowca na Wydziale Inżynierii Procesowej i Ochrony Środowiska Politechniki Łódzkiej.

e-mail: michal.glogowski@p.lodz.pl
[11] Rozporządzenie Parlamentu Europejskiego i Rady WE nr 443/2009 z dnia 23 kwietnia 2009 r. określające normy emisji dla nowych samochodów osobowych w ramach zintegrowanego podejścia Wspólnoty na rzecz zmniejszenia emisji $\mathrm{CO}_{2}$ z lekkich pojazdów dostawczych.

[12] Rozporządzenie Parlamentu Europejskiego i Rady UE nr 510/2011 z dnia 11 maja 2011 r. określające normy emisji dla nowych lekkich samochodów dostawczych w ramach zintegrowanego podejścia Unii na rzecz zmniejszenia emisji $\mathrm{CO}_{2}$ z lekkich pojazdów dostawczych.

[13] Saab Automobile, Internal combustion engine with variable compression, provided with reinforcements of the crankcase section in the region of the main bearings, International Patent Application - WO 92/09799, 11.06.1992.

[14] Tomar S., Mishra R., Bisht S., Kumar S., Balyan A., Saxena G., Optimisation of connecting rod design to achieve VCR, International Journal of Engineering Research and Applications, vol. 3, issue 6, 2013.

[15] Vianney Rabhi, Engine block and cylinder head assembly for a variable compression ratio engine, USA Patent Application - US 2010/0154748 A1, 24.06.2010.

Przemysław Łaziński, MSc. - a doctoral student at the Faculty of Mechanical Engineering of Lodz University of Technology.

Mgr inż. Przemyslaw Laziński - doktorant na Wydziale Mechanicznym Politechniki Łódzkiej.

e-mail: p.lazinski@wp.pl

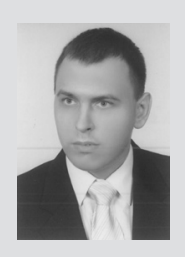

Jacek Leyko, DEng. - assistant professor at the Faculty of Mechanical Engineering of Lodz University of Technology.

Dr inż. Jacek Leyko - adiunkt na Wydziale Mechanicznym Politechniki Łódzkiej.

e-mail:leykoj@p.lodz.pl 